\title{
A Climate Change Projection for Summer Hydrologic Conditions in a Semiarid Watershed of Central Arizona
}

Gretchen A. Hawkins ${ }^{1}$, Enrique R. Vivoni ${ }^{1,2 *}$, Agustin Robles-Morua ${ }^{2,3}$, Giuseppe Mascaro ${ }^{1}$, Erick Rivera ${ }^{4}$, and Francina Dominguez ${ }^{4,5}$

1. School of Sustainable Engineering and the Built Environment

Arizona State University, Tempe, AZ, 85287

2. School of Earth and Space Exploration

Arizona State University, Tempe, AZ, 85287

3. Departamento de Ciencias del Agua y Medio Ambiente

Instituto Tecnológico de Sonora, Ciudad Obregón, Sonora, México.

4. Department of Atmospheric Science

University of Arizona, Tucson, AZ 85721

5. Department of Hydrology and Water Resources

University of Arizona, Tucson, AZ 85721

Revised for Journal of Arid Environments

JAE14-353

January 30, 2015

* Corresponding author address: Enrique R. Vivoni, School of Earth and Space Exploration, ISTB4, Building 75, Room 769, 781 E. Terrace Road, Arizona State University, Tempe, AZ, 85287-6004, tel: 480-727-3575, fax: 480-965-8102, email: vivoni@asu.edu. 


\begin{abstract}
Potential climate change impacts on summer precipitation and subsequent hydrologic responses in the southwestern U.S. are poorly constrained at present due to a lack of studies accounting for high resolution processes. In this investigation, we apply a distributed hydrologic model to the Beaver Creek watershed of central Arizona to explore its utility for climate change assessments. Manual model calibration and model validation were performed using radar-based precipitation data during three summers and compared to two alternative meteorological products to illustrate the sensitivity of the streamflow response. Using the calibrated and validated model, we investigated the watershed response during historical (1990-2000) and future (2031-2040) summer projections derived from a single realization of a mesoscale model forced with boundary conditions from a general circulation model under a high emissions scenario. Results indicate spatially-averaged changes across the two projections: an increase in air temperature of $1.2^{\circ} \mathrm{C}$, a 2.4 -fold increase in precipitation amount and a 3 -fold increase in variability, and a 3.1-fold increase in streamflow amount and a 5.1-fold increase in variability. Nevertheless, relatively minor changes were obtained in spatially-averaged evapotranspiration. To explain this, we used the simulated hydroclimatological mechanisms to identify that higher precipitation limits radiation through cloud cover leading to lower evapotranspiration in regions with orographic effects. This challenges conventional wisdom on evapotranspiration trends and suggest that a more nuanced approach is needed to communicate hydrologic vulnerability to stakeholders and decision-makers in this semiarid region.
\end{abstract}

Keywords: Watershed hydrology; climate change; distributed hydrologic model; North American Monsoon; evapotranspiration. 


\section{Introduction}

The vulnerability of the southwestern U.S. to climate change is of particular interest to water managers as this arid and semiarid region has historically been characterized by high hydroclimatic variability (Sheppard et al. 2002, Woodhouse et al. 2010). Dramatic changes to seasonal snowpack amounts or timing might lead to a decreased reliability in water supply as well as a reexamination of water infrastructure operations. For example, Christensen et al. (2004) found that impacts from climate change projections would degrade the performance of water supply and hydropower systems in the Colorado River. Similarly, Serrat-Capdevila et al. (2013) found that a range of projected impacts from climate change in the Verde River will influence downstream water supply in Phoenix, Arizona for the bimodal precipitation of the region. While prior studies have focused on the winter season (e.g., Christensen et al. 2004; Seager et al. 2007), relatively little is known regarding the regional vulnerability to changes in the summertime North American monsoon (NAM). Cook and Seager (2013) indicate the possibility of a delay in NAM timing (typically from July to September), while Serrat-Capdevila et al. (2013), Bukovsky et al. (2013) and Robles-Morua et al. (2015) found increases in NAM precipitation from a range of different climate projections. The implications of a change in the NAM are of regional interest, in particular for downstream water managers who might need to adapt operations and infrastructure to handle variations in the bimodal precipitation regime.

The NAM in the southwest U.S. is characterized by convective storms that are localized in nature and of short duration and high intensity, leading to flooding in small areas over short time periods (Adams and Comrie 1997, Gochis et al. 2006). As such, the use of coarse (monthly, $100 \mathrm{~km}$ resolution) general circulation models (GCMs) to provide inputs for regional watershed hydrology models has been criticized (see Wilby 2010, Kundzewicz and Stakhiv 2010). One 
approach to address this is through dynamical downscaling of GCM scenarios using mesoscale atmospheric models that can translate coarse projections into higher resolution (hourly, $10 \mathrm{~km}$ ) meteorological forcing. This can help improve the reliability of climate simulations in regions with fine-scale features such as rugged terrain, water bodies or land cover differences (Castro et al. 2007, Dominguez et al. 2012), leading to more realistic precipitation fields. Similarly, the use of coarse hydrologic models in climate change assessments limits their ability to resolve the finescale meteorological forcing and watershed properties that control hydrologic responses, in particular during the NAM (e.g., Ellis et al. 2008; Serrat-Capdevila et al. 2013, Robles-Morua et al. 2015). Distributed hydrologic models, on the other hand, have a wider appeal for climate change impact studies due to their ability to provide insight on the spatial and temporal details of the rainfall-runoff transformation (e.g., Xu and Singh 2004, Kampf and Burges 2007)

In this study, we conduct high resolution ( 120 m, hourly) hydrologic projections for summer conditions in a semiarid watershed of central Arizona. Our approach is based on developing meteorological fields over historical (1990-2000) and future (2031-2040) periods by using boundary conditions from a single GCM, the Hadley Center Coupled Model version 3 (HadCM3), with a mesocale simulation using the Weather Research and Forecasting (WRF) model. The meteorological fields are then applied as forcing in a distributed hydrologic model, known as the Triangulated Irregular Network (TIN)-based Real-time Integrated Basin Simulator (tRIBS), for the Beaver Creek watershed, located upstream of Phoenix, Arizona. Manual model calibration and model validation were performed using radar-based precipitation data during three summer seasons. Two additional products based on a rain gauge network and a reanalysis dataset were evaluated during these summer periods to illustrate the impacts of precipitation variability on the simulated hydrologic response. Hydroclimatological conditions during the 
NAM are then evaluated for historical and future periods to determine the propagation of precipitation and temperature changes into streamflow, soil moisture and evapotranspiration. We performed analyses of basin-averaged conditions across the two periods and the spatial distribution of differences between summer averages obtained for the two periods in an effort to quantify how spatial patterns aggregate to the entire Beaver Creek watershed. In doing so, we

identify and explain mechanistically how the climate change projection affects radiation and water availability that control evapotranspiration. Furthermore, this study provides a foundation upon which to build modeling activities that test a wider range of climate or land use change projections for supporting regional water managers in decision-making under uncertainty.

\section{Materials and Methods}

\subsection{Study Watershed and Its Characteristics}

The Beaver Creek watershed is a sub-watershed of the Verde River (Fig. 1). With an area of approximately $1100 \mathrm{~km}^{2}$, the watershed has variable terrain and landscape characteristics that are representative of the Mogollon Rim transition zone of central Arizona. Elevations range from $\sim 1,000$ to $2,600 \mathrm{~m}$ above sea level and are characterized by significant canyons incised into the Colorado Plateau. Land cover varies with elevation from desert shrub in the lowlands, through pinyon-juniper woodlands, and up to ponderosa pine forests at the higher elevations (e.g., Baker 1999; Lopes et al. 2001). Soils are composed primarily of clay, clay loam and loam, developed on basalts and cinders of volcanic origin. Table 1 presents the coverage of the major soil and land cover classes for the Beaver Creek watershed as determined from the data sources described in section 2.2.2. Summer precipitation during the NAM (July to September) in the watershed accounts for $\sim 40 \%$ of the annual total (Baker 1986), producing $\sim 15 \%$ of the annual streamflow (Baker 1982). The watershed is sampled by a network of ten automated rain gauges operated 
continuously by the Yavapai County Flood Control District and three continuous stream gauges (Dry Beaver Creek (USGS 09505350) near Rimrock, AZ, Wet Beaver Creek (USGS 09505200) near Rimrock, AZ, and Beaver Creek outlet (USGS 0950550) at Camp Verde, AZ) operated by the U.S. Geological Survey (USGS), with more limited data over 2004-2008 for the outlet site (Fig. 1). In addition, significant streamflow responses were identified at all stream gauging stations only during the summers of 2005 to 2007 , limiting our study period to this interval.

\subsection{Distributed Hydrologic Model and Its Application}

\subsubsection{Model Description}

The TIN-based Real-time Integrated Basin Simulator (tRIBS) was selected to conduct the summer season simulations in the Beaver Creek watershed. tRIBS is a spatially-explicit model of hydrologic processes (Ivanov et al. 2004; Vivoni et al. 2007). To make full use of the available geospatial datasets, tRIBS ingests terrain, soil, land cover, and meteorological conditions and resamples each to the model domain. A watershed is represented by a Triangulated Irregular Network (TIN) consisting of elevation, stream, and boundary nodes, which capture features with a reduced number of elements as compared to the original grid DEM (Vivoni et al. 2004). In tRIBS, Voronoi polygons are associated with each TIN node and serve as the finite-volume domain for water and energy balance calculations. For each Voronoi polygon, the model tracks the hydrologic response, including: (1) canopy interception; (2) evapotranspiration from bare soil and vegetated surfaces; (3) infiltration and soil moisture redistribution; (4) shallow subsurface flow; and (5) overland and channel flow. In prior studies, tRIBS has shown good performance with respect to hydrologic data in other semiarid watersheds (e.g., Vivoni et al. 2010; Mahmood and Vivoni 2011; Xiang et al. 2014). For this particular study, we emphasize the model ability to generate streamflow simulations at the outlet and interior locations as well as the time-averaged 
spatial distribution of soil moisture, runoff and evapotranspiration. Additional details on the model can be obtained from Ivanov et al. (2004) and Vivoni et al. (2007, 2010).

\subsubsection{Model Domain, Parameterization and Initialization}

Spatial inputs for the Beaver Creek watershed model application include topography, soil texture, land cover and initial depth to the groundwater table (Ivanov et al. 2004). The watershed domain was delineated from a 30 m Digital Elevation Model (DEM) obtained from the USGS (Fig. 1) and converted into a TIN using the hydrographic procedure described by Vivoni et al. (2004). A stream network that matched available hydrography was included in the model domain, resulting in 76,624 Voronoi polygons or an equivalent cell size, $r_{e}$, of approximately $120 \mathrm{~m}$ (Vivoni et al. 2005). This irregular sampling at high-resolution captures well the complex terrain (mesas, canyons, plateaus, valleys) of the Beaver Creek watershed as compared to coarser modeling efforts (4 to $12 \mathrm{~km}$ ) in the region (e.g., Ellis et al. 2008; Serrat-Capdevila et al. 2013). The spatial distribution of surface soil texture was obtained from a high-resolution Soil Survey Geographic (SSURGO) database consisting of 73 different classes (NRCS 2010), aggregated into the nine major texture types shown in Fig. 2a. Low-conductivity clay soils and bedrock occupy the canyon walls and large regions at intermediate elevations in the watershed. The spatial pattern of land cover was obtained from the LANDFIRE database (Rollins 2009) that depicts vegetation properties at $10 \mathrm{~m}$ resolution, as shown in Fig. 2b. Land cover classes follow an organization with elevation (desert shrub, pinyon-juniper woodland, ponderosa pine forest), along with small urban areas and roads (labeled General Development in Table 1 and Fig. 2). The spatial resolution and classification fidelity represented in the model exceed those in previous studies in the region (e.g., Ellis et al. 2008; Serrat-Capdevila et al. 2013). 
Model parameterization in terms of soil and vegetation conditions followed previous tRIBS applications where initial values were obtained from literature (e.g., Rawls et al. 1982, Mitchell et al. 2004, Ivanov et al. 2004, Vivoni et al. 2010, Robles-Morua et al. 2012) and assumed to be spatially uniform within each class. Table 3 lists the parameters associated with the dominant soil and land cover classes (see Hawkins 2012 for details). A manual calibration and validation exercise was conducted with respect to the observed streamflow at the three stream gauges for summer periods in 2005 (validation), 2006 (validation) and 2007 (calibration). These periods were selected based upon on simultaneous data availability from stream gauges, rain gauges and weather radar. To account for variations in the characteristics of the Wet and Dry Beaver Creek, the three main soil classes were treated separately in each sub-watershed. Manual model calibration involved varying soil and vegetation parameters to which the simulated streamflow was most sensitive within acceptable ranges, found to be the following parameters: saturated hydraulic conductivity $\left(K_{s}\right)$, hydraulic conductivity decay parameter $(f)$, air entry bubbling pressure $\left(\Psi_{b}\right)$, and pore size distribution index $(m)$ (also see Table 3 ). Manual calibration was based on prior studies using the model within semiarid and arid regions with complex terrain, for example Vivoni et al. (2010) and Robles-Morua et al. (2012). In addition, to help inform the calibration, Hawkins (2012) performed a simulation exercise at the Happy Jack station in the Wet Beaver Creek with respect to observed soil moisture and temperature at several depths for the summer of 2007, finding good agreement (not shown here for brevity).

Model initialization consists of specifying a spatially-distributed depth to the water table which sets the initial soil moisture profile at each Voronoi polygon based on the assumption of hydrostatic equilibrium (e.g., Ivanov et al. 2004). In the absence of field information, the initial groundwater depth can be obtained from a long-term (10 yr) drainage experiment as described by 
Vivoni et al. (2008b). This simulation allows a watershed to drain without any meteorological forcing from a completely saturated state under the influence of the specified terrain and soil properties. A rating curve between the groundwater state and the outlet streamflow is constructed as a means to initialize the model (Vivoni et al. 2008b). To do so, a spatially-variable depth to bedrock ranging from 5 to $15 \mathrm{~m}$ was assigned based upon the soil classification (Hawkins 2012). Fig. 2c presents the initial depth to groundwater assumed valid at the start of each summer period (June 1) leading to low streamflow $\left(<1 \mathrm{~m}^{3} / \mathrm{s}\right)$ at the Beaver Creek outlet. Thus, for the numerical experiments described next, the initial conditions were identical for all simulated summers.

\subsection{Numerical Experiments and Meteorological Forcing}

The numerical experiments consisted of two separate activities: (1) model calibration and validation for three summer periods (2005-2007), including a comparison across different meteorological products, and (2) model evaluations for historical (1990-2000) and future (20312040) summer projections. In all cases, simulations were conducted using the parallel computing capabilities in tRIBS (Vivoni et al. 2011) on the Arizona State University Saguaro cluster for periods from June 1 to September 30 of each year. For the first activity, we compared three types of meteorological forcings in the Beaver Creek watershed: a ground-based rain gauge network (Gauge), a precipitation product from the Next Generation Radar (NEXRAD) system, and a reanalysis dataset from the North American Land Data Assimilation System (NLDAS). Fig. 3 compares the total precipitation during each summer from the three sources. The Gauge product is obtained from 10 hourly rain gauges and includes an interpolation using Thiessen polygons. Large distances between rain gauges can result in a poor spatial representation of precipitation. To address this, we obtained hourly, $4 \mathrm{~km}$ resolution NEXRAD Stage IV precipitation observations which are corrected with ground-based rain gauges (see Grassotti et al. 2003, 
Vivoni et al. 2006). Note from Fig. 3 that NEXRAD resolves finer details in the summer precipitation in the watershed. For simulations with Gauge and NEXRAD, hourly meteorological variables (pressure, wind speed, air temperature and relative humidity) were specified from the Verde and Mormon weather stations at low and high elevations in the watershed (shown in Fig. 3). We evaluated NLDAS fields for all meteorological variables available at hourly, $12 \mathrm{~km}$ resolution (Mitchell et al. 2004), similar to the precipitation field shown in Fig. 3 for NLDAS. For this study, we used the raw NLDAS dataset without local corrections (e.g., Robles-Morua et al. 2012), to assess the capabilities of the native NLDAS product. Fig. 3 indicates that NLDAS generally captures the elevation gradient in meteorological forcing, but misses important details observed in the Gauge and NEXRAD products, as noted for other regions (e.g., Nan et al. 2010).

For the second activity, we applied mesoscale atmospheric simulations from the WRF model (Shamarock et al. 2005) which provides dynamically-downscaled, hourly precipitation and meteorological fields at $10 \mathrm{~km}$ resolution in the historical and future periods. Wi et al. (2012) describe the downscaling approach with the HadCM3 model boundary conditions and provide descriptions of the model setup. A WRF downscaling simulation at a $35 \mathrm{~km}, 6$ hour resolution over the coterminous U.S was first conducted and a second one-way downscaling step was performed to provide outputs at $10 \mathrm{~km}, 1$ hour resolution over a more limited domain $\left(28^{\circ}-37^{\circ}\right.$ N, $105^{\circ}-116^{\circ} \mathrm{W}$, Robles-Morua et al. 2011). As described by Wi et al. (2012), the downscaling approach utilized spectral nudging (Miguez-Macho et al. 2005) for the first step (35 km, $6 \mathrm{hr}$ ) to retain the synoptic-scale variability of the HadCM3 model. Dominguez et al. (2009) showed the HadCM3 model performed well in the southwest U.S. by capturing precipitation and temperature realistically. When averaged over the Beaver Creek watershed, the WRF simulations led to an underestimation of summer precipitation (June 1 to September 30) as compared to the NLDAS 
product during 1990-2000, with a mean daily difference of $0.83 \mathrm{~mm} /$ day or an underestimate of $101.7 \pm 52.5 \mathrm{~mm}$ over the summers. Based on the analysis of Cavazos and Arriaga-Ramírez (2012), it is likely that the underestimation in the WRF product during the historical period is related to the boundary conditions specified by HadCM3, which for the region exhibit a precipitation shift from summer to autumn, relative to observed precipitation patterns. Since this negative bias is consistent with Castro et al. (2012) and Robles et al. (2015), we applied the WRF simulations to the distributed hydrologic model without a bias correction to inspect the changes arising natively between the historical and future periods (see a discussion of the disadvantages of bias correction of climate simulations in Ehret et al. 2012). Nevertheless, it is important to note the WRF simulations represent one model-specific projection from which meteorological variables were obtained based on a single GCM and single emissions scenario. The future period (2031-2040) selected for dynamical downscaling with WRF is a 10-year time slice representative as reproduced by the HadCM3 model under a high (A2) emissions scenario (Mearns et al. 2012).

\section{Results and Discussion}

\subsection{Streamflow Simulations using Multiple Precipitation Products}

Depicting precipitation accurately from observations or simulations during the summer in the Beaver Creek watershed is challenging due to the complex terrain and the fine spatiotemporal scale of the storm systems (e.g., Baker 1982, Heinselman and Schultz 2006, Wall et al. 2012). As an example, Fig. 4 presents the spatial distribution of total precipitation for July 28, 2007, an event used within the model calibration exercise, for the three meteorological products. Note that the mean areal precipitation (MAP) is relatively low $(<25 \mathrm{~mm})$ in all products, but some rain gauges and NEXRAD pixels recorded accumulations greater than $50 \mathrm{~mm}$. Most precipitation occurred near the watershed outlet, downstream of the Wet and Dry Beaver Creek stream gauges 
(Fig. 1), in both the Gauge and NEXRAD products, while NLDAS spatially smoothens the storm event. The streamflow response for the event is shown in Fig. 5 over the period of July 27 to 30 , 2007. As expected from the NEXRAD data, spatial variations occur in the observed streamflow, with a low response at Dry Beaver Creek $\left(\sim 2 \mathrm{~m}^{3} / \mathrm{s}\right.$ in peak streamflow) and Wet Beaver Creek $\left(\sim 20 \mathrm{~m}^{3} / \mathrm{s}\right)$ and a larger event at the Beaver Creek outlet $\left(\sim 100 \mathrm{~m}^{3} / \mathrm{s}\right)$. Based on this evidence, NEXRAD data were used in the model calibration shown in Fig. 5 for all stream gauge sites. Overall, tRIBS simulates the observed streamflow well when using the NEXRAD data, including the variations in the peak streamflow among the stream gauges. A noticeable issue is the higher streamflow rates after the peak, in particular for the outlet. In contrast, simulations with Gauge and NLDAS products have more significant problems, such as delays and overestimations of the peak streamflow, which are symptomatic of the inaccuracies in the precipitation fields. Table 4 summarizes the model performance for the calibration period using NEXRAD data as well as the impact of forcing the model with Gauge and NLDAS products on three performance metrics.

Fig. 6 presents the simulated streamflow at the Beaver Creek stream gauges for the entire summer seasons during the calibration (2007) and validation (2005 and 2006) periods, presented as cumulative streamflow. These simulations correspond to the spatial precipitation patterns shown in Fig. 3 and are composed of individual storm events with varying spatiotemporal distributions. As noted for the single event in Fig. 5, NEXRAD produces the most accurate simulations with respect to the observed cumulative streamflow, in particular for the Wet and Dry Beaver Creek (see Table 4 for performance metrics for the three summer seasons and multiple forcing products). All simulations overestimate the observed streamflow at the Beaver Creek outlet, likely due to the lack of channel transmission losses in the tRIBS model (Ivanov et al. 2004), a process that is more important in the lower valleys with sedimentary fill. In general, 
the use of Thiessen polygon interpolation of rain gauges leads to larger errors than NEXRAD or NLDAS, an indication of the value of gridded ( 4 or $12 \mathrm{~km}$ cells) precipitation products. Errors in the Gauge simulations are due to spatial interpolation issues since Hawkins (2012) found correlation coefficients between NEXRAD pixels and Gauge sites of $\sim 0.8$ in 2007 . Furthermore, the gridded products provide a robust set of simulations across the three summers and their varied storm events at each stream gauge, suggesting the manual calibration and validation exercise yielded a model application to the Beaver Creek watershed suitable for analysis of summer conditions.

\subsection{Comparisons of Historical and Future Hydroclimatological Scenarios}

Assessing the impact of the climate change projection on the hydrologic response in the Beaver Creek watershed is performed first through an analysis of spatial averages for the historical (1990-2000) and future (2031-2040) periods. The spatial average considers eighteen WRF $(10 \mathrm{~km})$ model pixels within the watershed, an intermediate number between NEXRAD and NLDAS (see Fig. 3 as comparison). For clarity, all summer season simulations from June 1 to September 30 (11 and 10 summers in the historical and future periods, respectively) are shown as daily averages and \pm 1 standard deviations across all summers. Fig. 7 presents the spatiallyaveraged air temperature and precipitation for the historical and future periods. It is clear that the future projection exhibits a higher temperature (by $1.2^{\circ} \mathrm{C}$ on average over the summer) and an earlier warming to maximum temperatures (i.e., in late June as opposed to early August). Nearly the same interannual variability is observed in the two periods and the decline of air temperature during the end of the summer is also similar when averaged over all summers. A more dramatic change is observed in the spatially-averaged precipitation in the watershed, with an earlier onset of the NAM season ( 1 week) and a 2.4-fold increase in cumulative precipitation (i.e., from $\sim 80$ 
$\mathrm{mm}$ to $\sim 190 \mathrm{~mm}$ for the average conditions in each period). In addition, the interannual spread in summer precipitation grows substantially for the future period (i.e., larger \pm 1 standard deviations), indicating that the NAM might be susceptible more year-to-year variability.

Translating the climate projections to the Beaver Creek watershed response is conditioned on the hydrologic processes simulated by the model. As noted earlier, differences in meteorological observations (Gauge, NEXRAD and NLDAS) can lead to substantial variations in the simulated streamflow at the stream gauge sites. As a result, we should expect that a 2.4fold increase in precipitation and a higher variability in the future period should significantly impact the watershed response. Fig. 8 presents the Beaver Creek outlet streamflow and spatiallyaveraged evapotranspiration for the historical and future periods, shown as cumulative values. Clearly, the increase in summer precipitation and its variability translate directly to streamflow, with a higher (3.1-fold) increase and a significant rise in the interannual variability (a factor of 5.1) from the historical to the future period. Nevertheless, the fraction of precipitation converted into streamflow (i.e., seasonal runoff ratio) remains similar in the two periods $(\sim 2 \%$, Hawkins 2012), consistent with other analyses in the NAM region (Gochis et al. 2006; Vivoni et al. 2010). Interestingly, the cumulative evapotranspiration exhibits a small decrease when averaged over each period, but a larger interannual variability is observed in the future period. This suggests that despite the projected increase in summertime temperature and precipitation, both factors that increase evapotranspiration, there appear to be similar spatially-averaged water losses to the atmosphere. This contradicts prior studies asserting that warmer temperatures lead to higher evapotranspiration amounts in the region (e.g., Weiss et al. 2009, Gutzler and Robbins 2011). 


\subsection{Understanding Hydroclimatological Mechanisms via Distributed Modeling}

To explore further the climate change projection, we utilized the distributed hydrologic model to investigate the hydroclimatological differences between the historical and future periods. Since each summer used the same initial depth to groundwater on June 1, the effect of the initialization of soil moisture should not significantly impact the differences among the periods. Note that the simulated summertime evapotranspiration amounts (Fig. 8) exceed the seasonal precipitation during the NAM (Fig. 7). This is explained by the consumption of soil moisture and groundwater carried over from the winter and spring seasons as represented via the initial groundwater state, as in Mahmood and Vivoni (2011). Thus, Hawkins (2012) showed high daily evapotranspiration of $\sim 9 \mathrm{~mm} /$ day prior to the NAM (June), which stabilize to $\sim 5 \mathrm{~mm} / \mathrm{day}$ by the end of the NAM (September). During the NAM, spatially-averaged evapotranspiration is lower in the future period, despite warmer temperatures, suggesting that a limitation is present.

To address this, Fig. 9 presents the spatial distribution of differences in precipitation, surface soil moisture, runoff and evapotranspiration between the historical and future periods. In each case, the spatial maps represent the time-averaged variable across each summer in each period and the difference is taken as the future minus the historical (i.e., positive differences imply a greater quantity in the future and vice-versa). Interestingly, precipitation increases are spatially organized with higher values (+130 to $150 \mathrm{~mm}$, Fig. 9a) in the Mogollon Rim area with large elevation changes, consistent with observations (Fig. 3). This demonstrates the advantages of using a mesoscale model in that orographic effects on precipitation can be captured more realistically (e.g., Castro et al. 2012; Tripathi and Dominguez 2013). Relative soil moisture differences exhibit a small increase in the future period $(+0.001$ to 0.03 , Fig. $9 b)$ when timeaveraged over each summer, attributed to higher precipitation amounts. A notable feature is the 
downstream increase in positive soil moisture differences due to horizontal connectivity in the model, overlaid on the effect of soil texture variations (Fig. 3). Downstream moistening suggests that locations near channel networks benefit hydrologically in the future period. Horizontal connectivity also impacts spatial runoff differences with some upland areas exhibiting a decrease in runoff in the future period (-0.01 to $0.9 \mathrm{~mm}$, Fig. $9 \mathrm{c})$, but the major spatial controls on runoff patterns are due to soil texture differences. Over most of the basin, runoff is projected to increase in the future period, with higher values $(+0.3$ to $1.7 \mathrm{~mm})$ in areas with low conductivity clay soils and bedrock. Clearly, rich spatial patterns are observed in runoff differences as a superposition of precipitation changes and the underlying soil, terrain and land cover properties. Precipitation and soil moisture increases should lead to higher evapotranspiration due to the control of water availability on this process in a semiarid setting (e.g., Vivoni et al. 2008a). However, as noted previously, the spatially-averaged evapotranspiration does not appreciably change between the historical and future periods. Fig. 9d illustrates that the spatial pattern of evapotranspiration differences are complex, with a strong imprint of the precipitation distribution (i.e., $10 \mathrm{~km}$ WRF cells as in Fig. 9a). Notably, large decreases in evapotranspiration (-60 to 195 $\mathrm{mm}$ ) occur in pixels that receive larger precipitation from orographic forcing. This suggests that the limit on evapotranspiration is related to the spatial scale of storm events, captured by WRF at $10 \mathrm{~km}$ resolution, and thus to the radiation limitation imposed by cloud cover in those pixels. This is captured in tRIBS by ingesting the $10 \mathrm{~km}$, hourly resolution shortwave radiation incident on the land surface as simulated by WRF for each period. As evidence of this, the simulated daily-averaged shortwave radiation forcing decreases from the historical $\left(347 \pm 2.5 \mathrm{~W} / \mathrm{m}^{2}\right)$ to the future $\left(341 \pm 4.3 \mathrm{~W} / \mathrm{m}^{2}\right)$ periods. Nevertheless, there are some regions in Dry Beaver Creek with an increase in evapotranspiration ( +0 to $35 \mathrm{~mm}$ ) related to higher local water availability in 
specific soil classes and a smaller effect of the cloud cover limitation. When spatially averaged over the Beaver Creek watershed, the evapotranspiration differences in the two periods are small as regions of positive and negative changes compensate for one another.

\section{Summary and Conclusions}

This study used a distributed hydrologic model to evaluate the hydrologic consequences of a climate change projection in the Beaver Creek watershed of central Arizona. Summer season simulations were driven with radar-based precipitation during the model calibration and validation exercise and evaluated using two alternative meteorological products at three stream gauge sites, yielding an adequate model performance. Based on the calibrated and validated model, the hydrologic response during summer seasons in a historical (1990-2000) and a future (2031-2040) projection were compared in terms of precipitation, soil moisture, runoff and evapotranspiration for spatially-averaged temporal variations and for time-averaged spatial patterns. Comparisons showed an increase in temperature, a large increase in precipitation amount and variability, and an amplified increase in streamflow amount and variability in the future period. However, relatively minor changes were obtained in the spatially-averaged evapotranspiration, though a larger interannual variability was observed. We explained the unexpected outcome related to evapotranspiration through the hydroclimatological mechanisms for each period, finding a compensating effect of higher cloud cover that limited radiation despite the higher summertime water availability in the future projection. This result challenges conventional wisdom on evapotranspiration trends resulting from climate change studies, which usually anticipate large future increases in evapotranspiration due to higher air temperatures (e.g., Weiss et al. 2009, Gutzler and Robbins 2011). 
Prior studies have documented that higher evapotranspiration might not occur in semiarid regions if there is low water availability (Vivoni et al. 2009) or a stomatal control by vegetation (Serrat-Capdevila et al. 2011). In this work, we find that a radiation limitation can also control evapotranspiration due to higher cloud cover induced in a future climate projection with higher precipitation, in spite of more soil water and warmer temperatures. This suggests that climate change projections related to evapotranspiration need to be carefully analyzed with respect to the biotic and abiotic limits on the process, with warmer temperatures playing a role within a broader suite of conditions (i.e., radiation, water availability, vapor pressure deficit). In addition, the distributed hydrologic simulations performed here indicate that compensating effects can occur when complex spatial patterns of evapotranspiration are aggregated to an entire watershed. Both of these issues suggest that a more nuanced approach might be required when communicating the results of climate change projections to water managers in the arid and semiarid regions of the southwestern U.S. where the North American monsoon is an important seasonal phenomenon.

This study is based on one climate change scenario over a short period in the near future (2031-2040) using the HadCM3 model boundary conditions, A2 emissions scenario and dynamical downscaling using WRF, thus limiting its generality with respect to all possible future climate projections for the region. Furthermore, the WRF downscaling of the HadCM3 model underestimated precipitation substantially during the historical period as compared to the NLDAS product, consistent with Castro et al. (2012) and Robles-Morua et al. (2015). Applying a bias correction derived in the historical period (i.e., based on comparisons to regional data) would likely lead to a much wetter future period, where the results of our analysis would still likely hold. Other combinations of GCM boundary conditions, dynamical downscaling techniques and emissions scenarios (e.g., Mearns et al. 2012; Bukovsky et al. 2013) will yield 
differing impacts on summer precipitation that ultimately would produce varying hydrologic responses. For cases with a reduction in summer precipitation, we might expect lower soil moisture and streamflow, while evapotranspiration changes would depend upon the level of water stress present in the region rather than on cloud cover effects.

Despite the limitation of a single realization, the approach taken here demonstrates a more realistic use of a climate change projection in a watershed simulation, due to the improved spatial representation of orographic precipitation and its influence on radiation through cloud cover. The distributed hydrologic model also allows a detailed spatiotemporal representation of the effects of a climate change projection to be translated into hydrologic conditions of interest to downstream water managers in Phoenix, Arizona. As a result, this study provides a foundation upon which to build future modeling activities that test a wider range of climate or land use change projections on water resources that can support decision-making under uncertainty (e.g., Gober et al. 2010, White et al. 2010). Clearly, hydrologic vulnerabilities emanating from climate change projections might be considered contrary to conventional wisdom and this needs to be properly communicated to stakeholders and decision-makers with interests in a region.

\section{Acknowledgements}

This material is based upon work supported by the National Science Foundation under award SES-0951366 Decision Center for a Desert City II: Urban Climate Adaptation and award DEB-1038651 Climate and Population Change and Thresholds of Peak Ecological Water: Integrated Synthesis for Dryland Rivers. We thank contributions from Dave White, Hernan Moreno and Margaret Nelson to the study. We thank an anonymous reviewer and the journal editor for useful comments that helped improve the manuscript. 


\section{References}

Adams, D.K. and Comrie, A.C. 1997. The North American monsoon. Bulletin of the American Meteorological Society, 78: 2197-2213.

Baker, M.B. 1982. Hydrologic regimes of forested areas in the Beaver Creek watersheds. Gen. Tech. Rep. RM-90, Fort Collins, CO: U.S. Department of Agriculture, Forest Service, Rocky Mountain Research Station. 8 pp.

Baker, M.B. 1986. Effects of ponderosa pine treatment on water yield in Arizona. Water Resources Research, 22(1): 67-73.

Baker, M.B. 1999. History of watershed research in the central Arizona highlands. Gen. Tech. Rep. RMRS-GTR-29. Fort Collins, CO: U.S. Department of Agriculture, Forest Service, Rocky Mountain Research Station. 56 pp.

Bukovsky, M.S., Gochis, D.J. and Mearns, L.O. 2013. Towards assessing NARCCAP regional climate model credibility for the North American monsoon: Current climate simulations. Journal of Climate, 26(22): 8802-8826.

Castro, C.L., Pielke, R.A., Adegoke, J.O., Schubert, S.D. and Pegion, P.J. 2007. Investigation of the summer climate of the contiguous U.S. and Mexico using the regional atmospheric modeling system (RAMS). Journal of Climate, 20: 3888-3901.

Castro, C.L., Chang, H-I., Dominguez, F., Carrillo, C., Schemm, J-K. and Juang, H-M.H. 2012. Can a regional climate model improve the ability to forecast the North American monsoon? Journal of Climate, 25: 8212-8237.

Cavazos, T. and Arriaga-Ramírez, S. 2012. Downscaled climate change scenarios for Baja California and the North American monsoon during the twenty-first century. Journal of Climate, 25: 5904-5915. 
Christensen, N.S., Wood, A.W., Voisin, N., Lettenmaier, D.P. and Palmer, R.N. 2004. The effects of climate change on the hydrology and water resources of the Colorado River basin. Climatic Change, 62: 337-363.

Cook, B.I. and Seager, R. 2013. The response of the North American monsoon to increased greenhouse gas forcing. Journal of Geophysical Research - Atmospheres, 118(4): 16901699.

Dominguez, F., Cañon, J. and Valdes, J.B. 2009. IPCC-AR4 climate simulations for the southwestern US: The importance of future ENSO projections. Climatic Change, 99 (3-4): 499-514.

Dominguez, F., Rivera, E., Lettenmaier, D.P. and Castro, C.L. 2012. Changes in winter precipitation extremes for the western United States under a warmer climate as simulated by regional climate models. Geophysical Research Letters, 39: L05803, doi:10.1029/2011GL050762.

Ehret, U., Zehe, E., Wulfmeyer, V., Warrach-Sagi, K. and Liebert, J. 2012. Should we apply bias correction to global and regional climate model data? Hydrology and Earth System Sciences, 16: 3391-3404.

Ellis, A.W., Hawkins, T.W., Balling, R.C. and Gober, P. 2008. Estimating future runoff levels for a semi-arid fluvial systems in central Arizona, USA. Climate Research, 35: 227-239.

Gober, P., Kirkwood, C.W., Balling, R.C., Ellis, A.W. and Deitrick, S. 2010. Water planning under climatic uncertainty in Phoenix: Why we need a new paradigm. Annals of the Association of American Geographers, 100(2): 356-372.

Gochis, D.J., Brito-Castillo, L. and Shuttleworth, W.J. 2006. Hydroclimatology of the North American monsoon region in northwest Mexico. Journal of Hydrology, 316: 53-70. 
Grassotti, C., Hoffman, R.N., Vivoni, E.R. and Entekhabi, D. 2003. Multiple timescale intercomparison of two radar products and rain gauge observations over the Arkansas-Red River Basin. Weather and Forecasting, 18(6): 1207-1229.

Gutzler, D.S. and Robbins, T.O. 2011. Climate variability and projected change in the western United States: regional downscaling and drought statistics. Climate Dynamics, 37: 835-849.

Hawkins, G. 2012. Assessing the effects of climate change in a semiarid basin utilizing a fully distributed hydrologic Model: A case study of Beaver Creek, Arizona. M.S. Thesis in Civil, Environmental and Sustainable Engineering, Arizona State University, 121 pp.

Heinselman, P.L. and Schultz, D.M. 2006. Intraseasonal variability of summer storms over central Arizona during 1997 and 1999. Weather and Forecasting, 21: 559-578.

Ivanov, V.Y., Vivoni, E.R., Bras, R.L. and Entekhabi, D. 2004. Catchment hydrologic response with a fully-distributed triangulated irregular network model. Water Resources Research, 40(11): W11102, 10.1029/2004WR003218.

Kampf, S.K. and Burges, S.J. 2007. A framework for classifying and comparing distributed hillslope and catchment hydrologic models. Water Resources Research, 43: W05423, doi:10.1029/2006WR005370.

Kundzewicz, Z.W. and Stakhiv, E.Z. 2010. Are climate models "ready for prime time" in water resources management applications, or is more research needed? Editorial. Hydrological Science Journal, 55(7): 1085-1089.

Lopes, V.L., Ffolliott, P.F. and Baker, M.B. 2001. Impacts of vegetative practices on suspended sediment from watersheds of Arizona. Journal of Water Resources Planning and Management, 127(1): 41-47. 
Mahmood, T.H. and Vivoni, E.R. 2011. A climate-induced threshold in hydrologic response in a semiarid ponderosa pine hillslope. Water Resources Research, 47: W09529, doi:10.1029/2011WR010384.

Mearns, L.O. and co-authors, 2012. The North American Regional Climate Change Assessment Program: Overview of Phase I Results. Bulletin of the American Meteorological Society, 93(9): 1337-1362.

Miguez-Macho, G., Stenchikov, G.L. and Robock, A. 2005. Regional climate simulations over North America: Interaction of local processes with improved large-scale flow. Journal of Climate, 18: 1227-1246.

Mitchell, K.E., and co-authors, 2004. The multi-institution North American Land Data Assimilation System (NLDAS): Utilizing multiple GCIP products and partners in a continental distributed hydrological modeling system. Journal of Geophysical Research, 109: D07S90, doi:10.1029/2003JD003823.

Nan, Z., Wang, S., Liang, X. and Adams, T.E. 2010. Analysis of spatial similarities between NEXRAD and NLDAS precipitation data products. Journal of Selected Topics in Applied Earth Observations and Remote Sensing, 3: 371-385.

Natural Resources Conservation Service (NRCS). 2010. Custom Soil Resource Report for Beaver Creek Area, Arizona. United States Department of Agriculture, 78 pp.

Rawls, W.J., Brakensiek, D.L. and Saxton, K.E. 1982. Estimation of soil water properties. Transactions of the ASAE, 25: 1316-1320.

Robles-Morua, A., Vivoni, E.R., Volo, T., Rivera-Fernandez, E., Dominguez, F. and Meixner, T. 2011. Fine-resolution modeling of the Santa Cruz and San Pedro river basins for climate 
change and riparian system studies. American Geophysical Union Fall Meeting, Abstract H33D-1346, San Francisco, CA.

Robles-Morua, A., Vivoni, E.R. and Mayer, A.S. 2012. Distributed hydrologic modeling in northwest Mexico reveals the links between runoff mechanisms and evapotranspiration. Journal of Hydrometeorology, 13: 785-807.

Robles-Morua, A., Che, D., Mayer, A.S. and Vivoni, E.R. 2015. Hydrologic assessment of proposed reservoirs in the Sonora River basin, Mexico, under historical and future climate scenarios. Hydrological Sciences Journal, 60(1): 50-66.

Rollins, M.G. 2009. LANDFIRE: A nationally consistent vegetation, wildfire, and fuel assessment. International Journal of Wildland Fire, 18(3): 235-249.

Seager, R., and co-authors, 2007. Model projections of an imminent transition to a more arid climate in southwestern North America. Science, 36: 1181-1184.

Serrat-Capdevila, A., Scott, R.L., Shuttleworth, W.J. and Valdes, J.B. 2011. Estimating evapotranspiration under warmer climates: Insights from a semi-arid riparian system. Journal of Hydrology, 399: 1-11.

Serrat-Capdevila, A., Valdes, J.B., Dominguez, F. and Rajagopal, S. 2013. Characterizing the water extremes of the new century in the US South-west: A comprehensive assessment from state-of-the-art climate model projections. International Journal of Water Resources Development, 29(2): 152-171.

Sheppard, P.R., Comrie, A.C., Packin, G.D., Angersbach, K. and Hughes, M.K. 2002. The climate of the US southwest. Climate Research, 21(3): 219-238.

Skamarock, W.C., Klemp, J.B., Dudhia, J., Gill, D.O., Barker, D.M., Wang, W. and Powers, J. G. 2005. A description of the advanced research WRF version 2. NCAR Tech. Note, 88 pp. 
Tripathi, O.P. and Dominguez, F. 2013. Effects of spatial resolution in the simulation of daily and subdaily precipitation in the southwest US. Journal of Geophysical Research Atmospheres, 118: 7591-7605.

Vivoni, E.R., Ivanov, V.Y., Bras, R.L. and Entekhabi, D. 2004. Generation of triangulated irregular networks based on hydrological similarity. Journal of Hydrologic Engineering, 9(4): 288-302.

Vivoni, E.R., Ivanov, V.Y., Bras, R.L. and Entekhabi, D. 2005. On the effects of triangulated terrain resolution on distributed hydrologic model response. Hydrological Processes, 19(11): 2101-2122.

Vivoni, E.R., Entekhabi, D., Bras, R.L., Ivanov, V.Y., Van Horne, M.P., Grassotti, C. and Hoffman, R.N. 2006. Extending the predictability of hydrometeorological flood events using radar rainfall nowcasting. Journal of Hydrometeorology, 7(4): 660-677.

Vivoni, E.R., Entekhabi, D., Bras, R.L. and Ivanov, V.Y. 2007. Controls on runoff generation and scale-dependence in a distributed hydrologic model. Hydrology and Earth System Sciences, 11(5): 1683-1701.

Vivoni, E.R., Moreno, H.A., Mascaro, G., Rodriguez, J.C., Watts, C.J., Garatuza-Payan, J. and Scott, R.L. 2008a. Observed relation between evapotranspiration and soil moisture in the North American monsoon region. Geophysical Research Letters, 35: L22403, doi:10.1029/2008GL036001.

Vivoni, E.R., Di Benedetto, F., Grimaldi, S. and Eltahir, E.A.B. 2008b. Hypsometric control on surface and subsurface runoff. Water Resources Research, 44: W12502, doi:10.1029/2008WR006931. 
Vivoni, E.R., Aragon, C.A., Malczynski, L. and Tidwell, V. C. 2009. Semiarid watershed response in central New Mexico and its sensitivity to climate variability and change. Hydrology and Earth System Science, 9: 715-733.

Vivoni, E.R., Rodriguez, J.C. and Watts, C.J. 2010. On the spatiotemporal variability of soil moisture and evapotranspiration in a mountainous basin within the North American monsoon region. Water Resources Research, 46: W02509, doi:10.1029/2009WR008240.

Vivoni, E.R., Mascaro, G., Mniszewski, S., Fasel, P., Springer, E.P., Ivanov, V.Y. and Bras, R.L. 2011. Real-world hydrologic assessment of a fully-distributed hydrological model in a parallel computing environment. Journal of Hydrology, 409: 483-496.

Wall, C.L., Zipser, E.J. and Liu, C. 2012. A regional climatology of monsoonal precipitation in the southwestern United States using TRMM. Journal of Hydrometeorology, 13: 310-323.

Weiss, J.L., Castro, C.L. and Overpeck, J.T. 2009. Distinguishing pronounced droughts in the southwestern United States: seasonality and effects of warmer temperatures. Journal of Climate, 22: 5918-5932.

White, D.D., Wutich, A., Larson, K.L., Gober, P., Lant, T. and Senneville, C. 2010. Credibility, salience, and legitimacy of boundary objects: Water managers' assessment of a simulation model in an immersive decision theater. Science and Public Policy, 37: 219-232.

Wi, S., Dominguez, F., Durcik, M., Valdes, J.B., Diaz, H.F. and Castro, C.L. 2012. Climate change projection of snowfall in the Colorado River basin using dynamical downscaling. Water Resources Research, 48: W05504, doi: 10.1029/2011WR010674.

Wilby, R.L. 2010. Evaluating climate model outputs for hydrological applications - Opinion. Hydrological Sciences Journal, 55(7): 1090-1093. 
Woodhouse, C.A., Meko, D.M., MacDonald, G.M., Stahle, D.W. and Cooke, E.R. 2010. A 1,200 year perspective of $21^{\text {st }}$ century drought in southwestern North America. Proceedings of the National Academy of Sciences, 107(50): 21283-21288.

Xiang, T.T., Vivoni, E.R. and Gochis, D.J. 2014. Seasonal evolution of ecohydrological controls on land surface temperature over complex terrain. Water Resources Research, 50(5): 38523874.

Xu, C.Y. and Singh, V.P. 2004. Review on regional water resources assessment models under stationary and changing climate. Water Resources Management, 18(6): 591-612. 


\section{Figure Captions}

Fig. 1. Beaver Creek watershed location within the Verde River in central Arizona (inset). Watershed representation through a $30 \mathrm{~m}$ Digital Elevation Model (DEM) and the locations of stream gauges, rain gauges and sub-watershed boundaries (Wet and Dry Beaver Creek).

Fig. 2. Spatial distributions of soil texture classes (A), land cover classes (B) and initial depth to the groundwater table $(\mathrm{C})$.

Fig. 3. Spatial distribution of total precipitation for three summer periods from Gauge, NEXRAD $(4 \mathrm{~km})$ and NLDAS $(12 \mathrm{~km})$ products over Beaver Creek (with watershed boundary shown).

Fig. 4. Spatial distribution of total event precipitation on July 28, 2007 from Gauge, NEXRAD and NLDAS products, with the watershed boundary and mean areal precipitation (MAP) shown.

Fig. 5. Simulated and observed streamflow at the three stream gauges (July 27 to 30, 2007) from Gauge, NEXRAD and NLDAS products with the spatially-averaged precipitation shown.

Fig. 6. Simulated and observed cumulative streamflow (June 1 to September 30) for the three summer periods at the three stream gauges from the Gauge, NEXRAD and NLDAS products.

Fig. 7. Historical and future summertime climate projections spatially-averaged in the Beaver Creek of air temperature (A, B) and cumulative precipitation (C, D) averaged over each period (solid lines) and with interannual variability ( \pm 1 standard deviation shown as bars or shading).

Fig. 8. Historical and future summertime climate projections spatially-averaged in the Beaver Creek of cumulative outlet streamflow (A, B) and cumulative evapotranspiration (C, D) averaged over each period (solid lines) and with interannual variability ( \pm 1 standard deviation, shading). 
Fig. 9. Spatial variation of climate projection differences (average future period minus average historical period) in the Beaver Creek watershed for precipitation (A), relative soil moisture which is normalized by porosity (B), runoff (C) and evapotranspiration (D). Units are shown as a difference in $\mathrm{mm}$ and valid over an entire summer season (June 1 to September 30). 


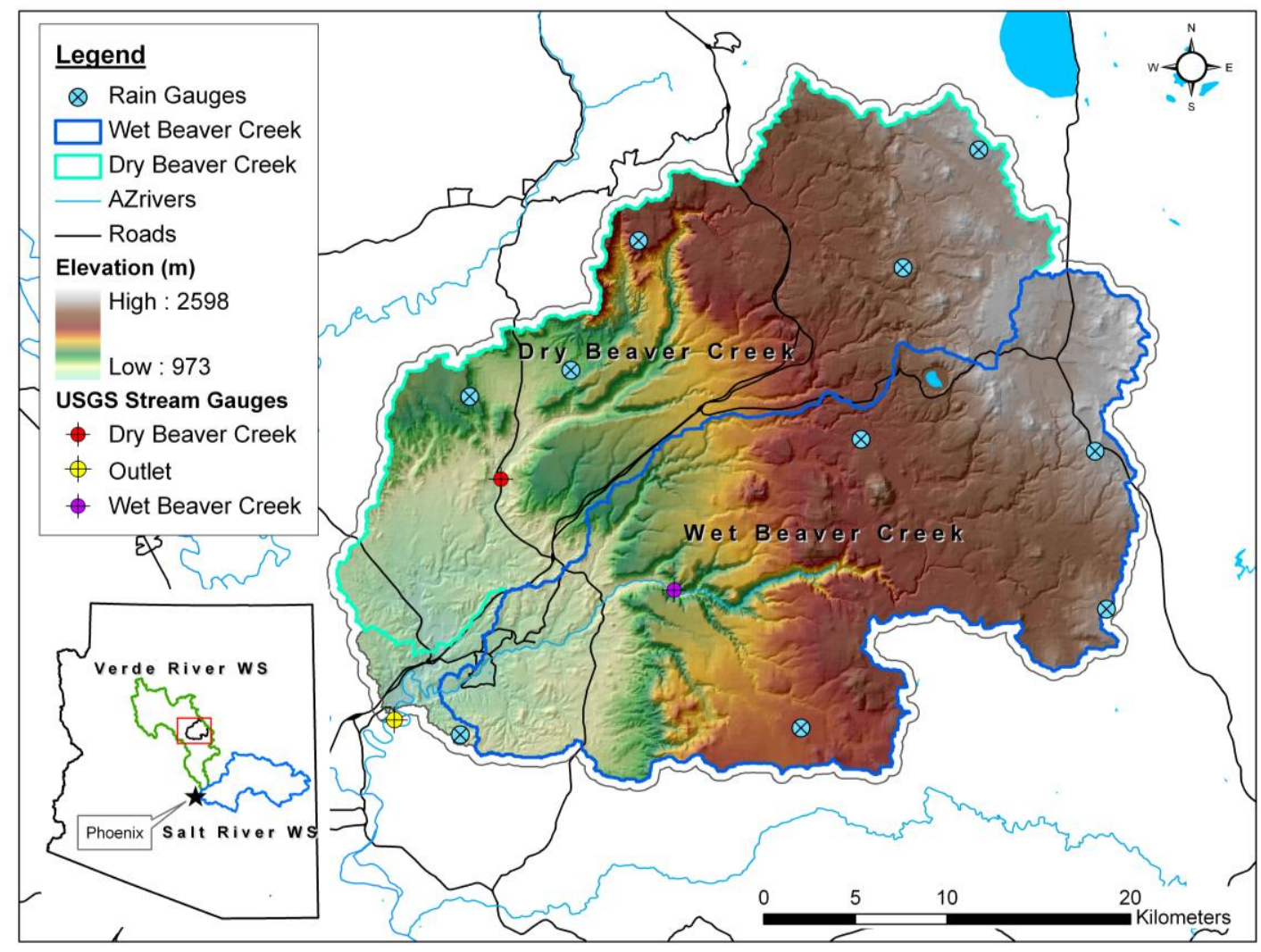

Fig. 1. Beaver Creek watershed location within the Verde River in central Arizona (inset). Watershed representation through a $30 \mathrm{~m}$ Digital Elevation Model (DEM) and the locations of stream gauges, rain gauges and sub-watershed boundaries (Wet and Dry Beaver Creek).

Fig. 1 (Hawkins et al. 2015) 


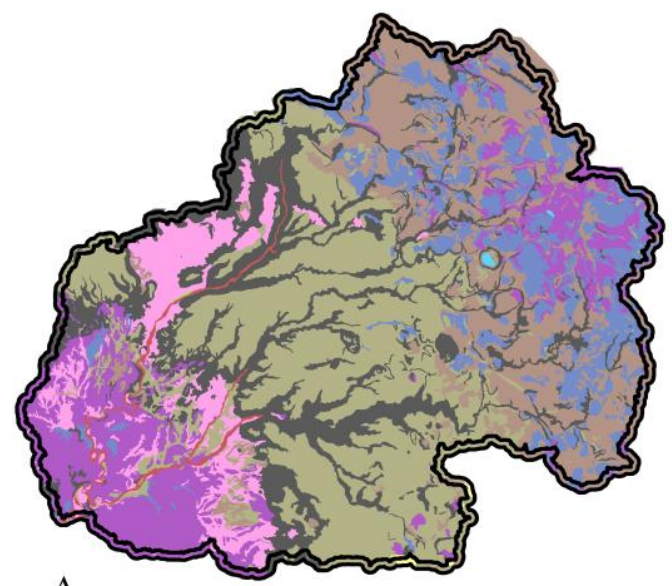

A.

Legend

A. Soil Classes

Bedrock

Clay

Clay loam

Loam

Loamy sand

Sand

Sandy Loam

- Silt Loam

Silty clay loam

Water

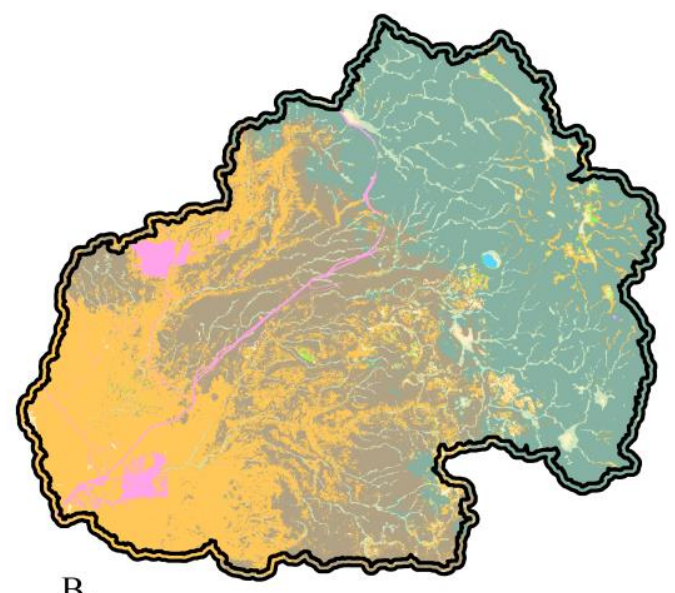

B.

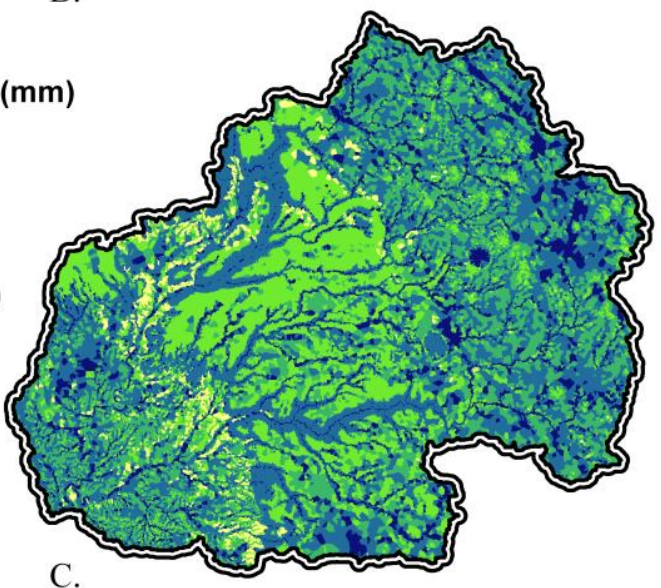

Fig. 2. Spatial distributions of soil texture classes (A), land cover classes (B) and initial depth to the groundwater table (C).

Fig. 2 (Hawkins et al. 2015) 


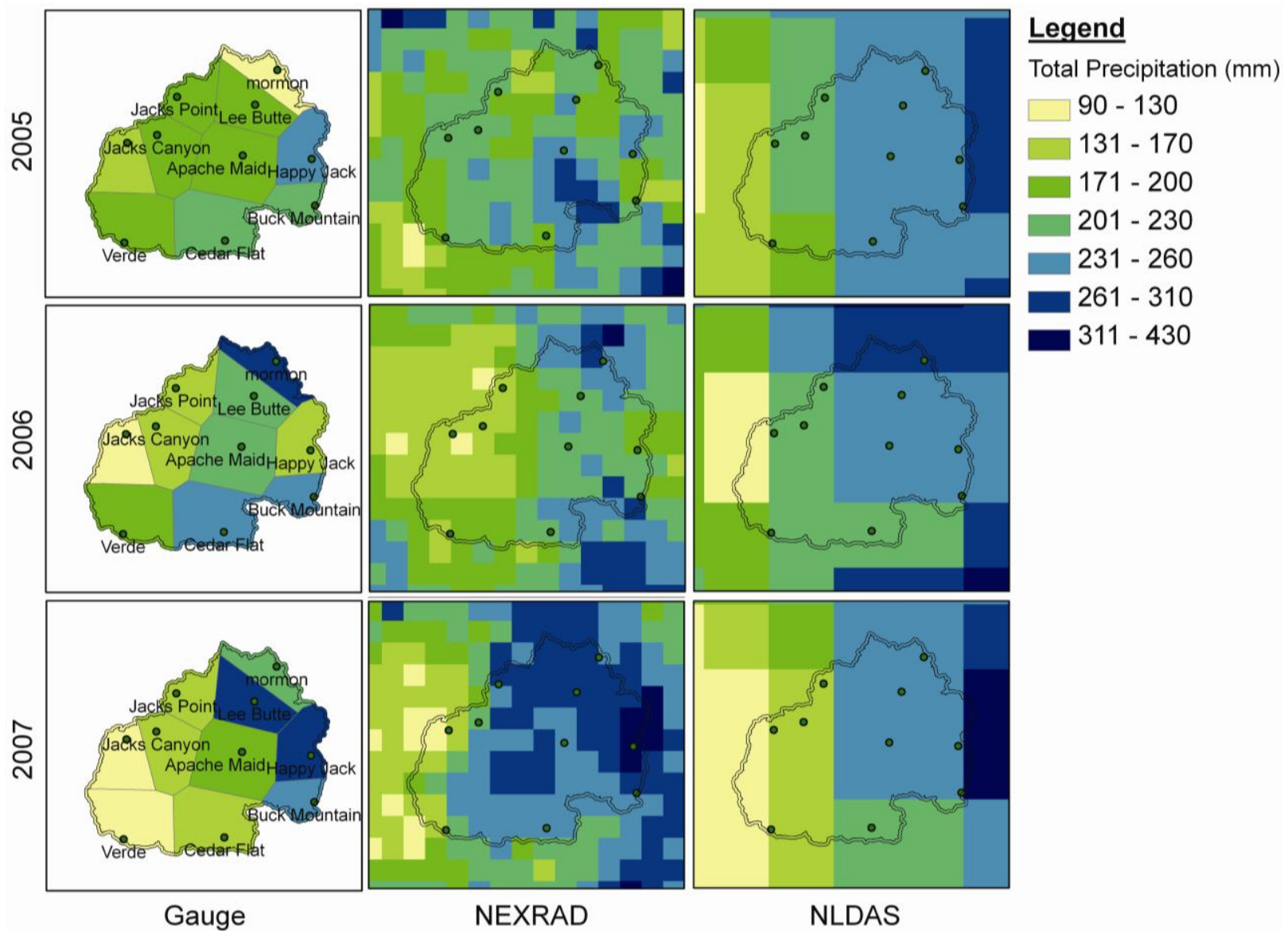

Fig. 3. Spatial distribution of total precipitation for three summer periods from Gauge, NEXRAD $(4 \mathrm{~km})$ and NLDAS $(12 \mathrm{~km})$ products over Beaver Creek (with watershed boundary shown).

Fig. 3 (Hawkins et al. 2015) 

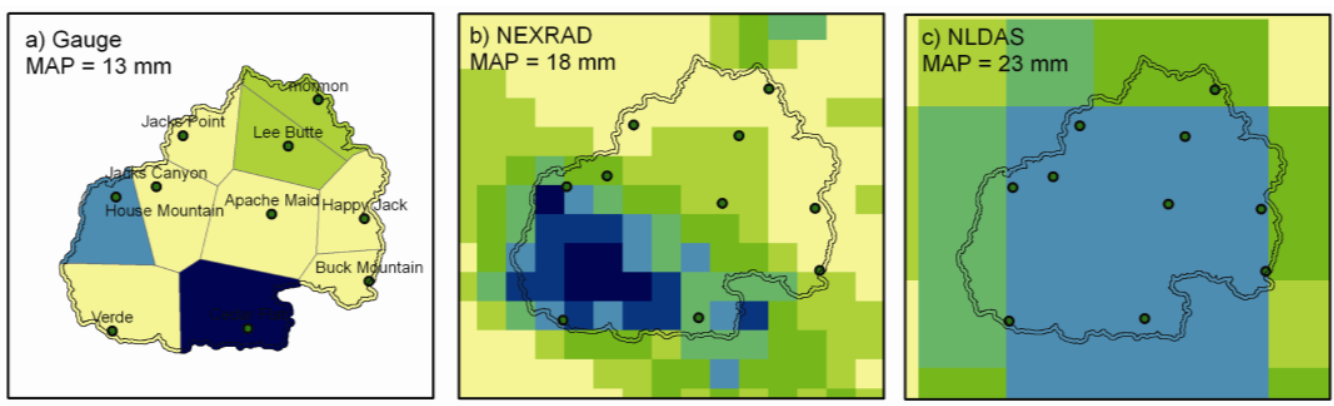

Legend
Precipitation (mm)
\begin{tabular}{|c|}
\hline $1-5$ \\
$6-10$ \\
$11-15$ \\
$16-20$ \\
$21-30$ \\
$31-40$ \\
$41-60$
\end{tabular}

Fig. 4. Spatial distribution of total event precipitation on July 28, 2007 from Gauge, NEXRAD and NLDAS products, with the watershed boundary and mean areal precipitation (MAP) shown.

Fig. 4 (Hawkins et al. 2015) 

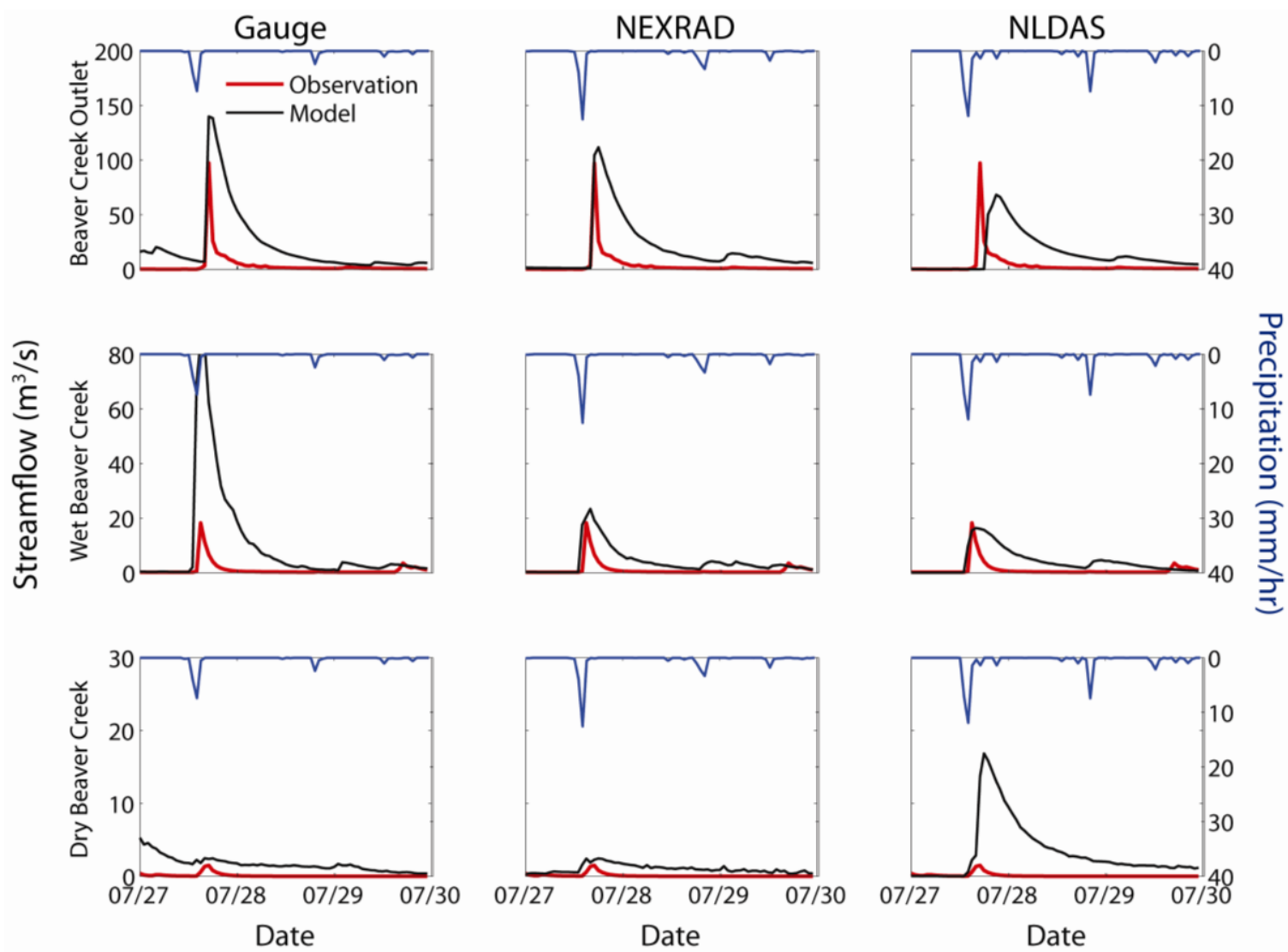

Fig. 5. Simulated and observed streamflow (July 27 to 30, 2007) at the three stream gauges from the Gauge, NEXRAD and NLDAS products with the spatially-averaged precipitation shown.

Fig. 5 (Hawkins et al. 2015) 

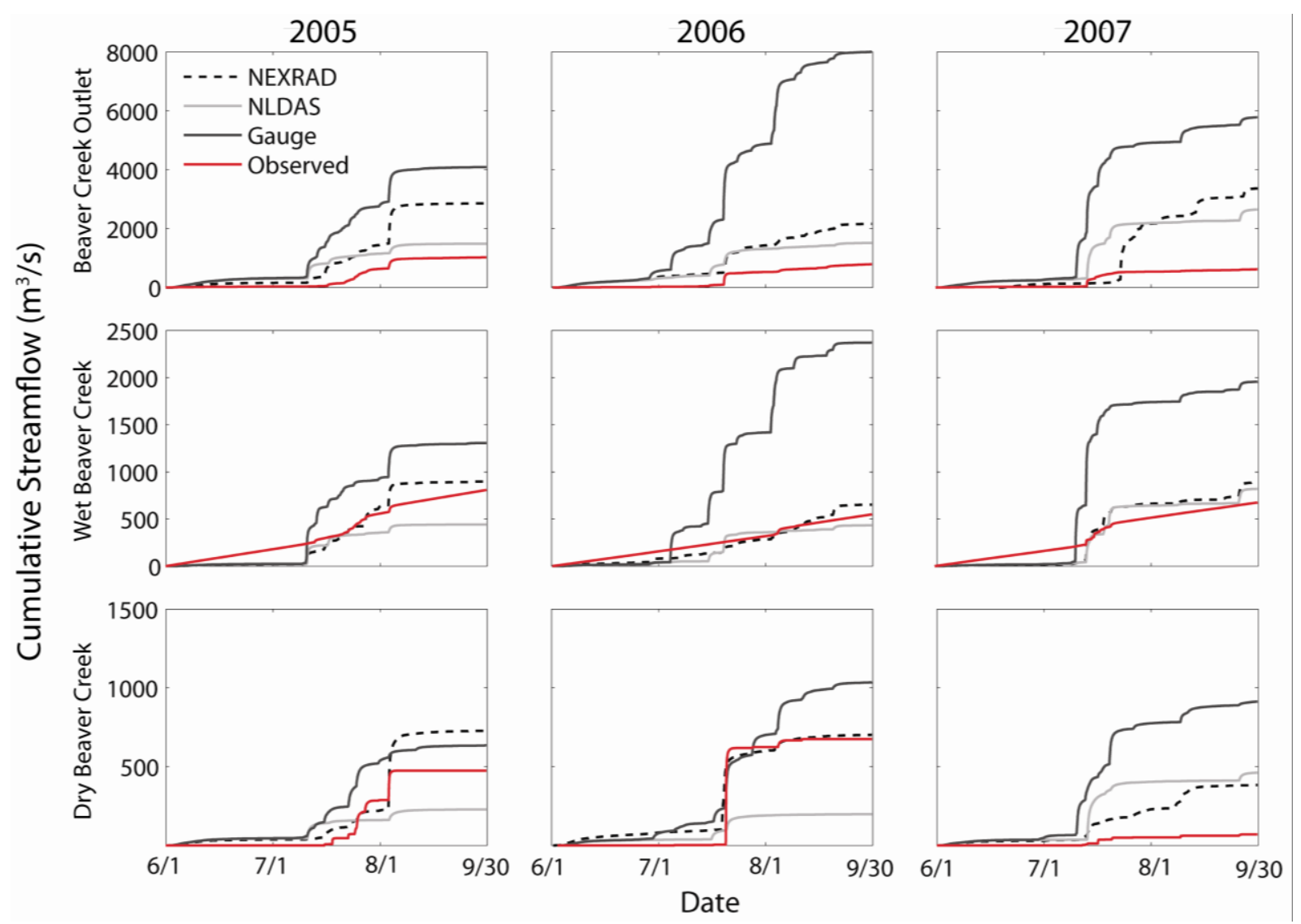

Fig. 6. Simulated and observed cumulative streamflow (June 1 to September 30) for the three summer periods at the three stream gauges from the Gauge, NEXRAD and NLDAS products.

Fig. 6 (Hawkins et al. 2015) 

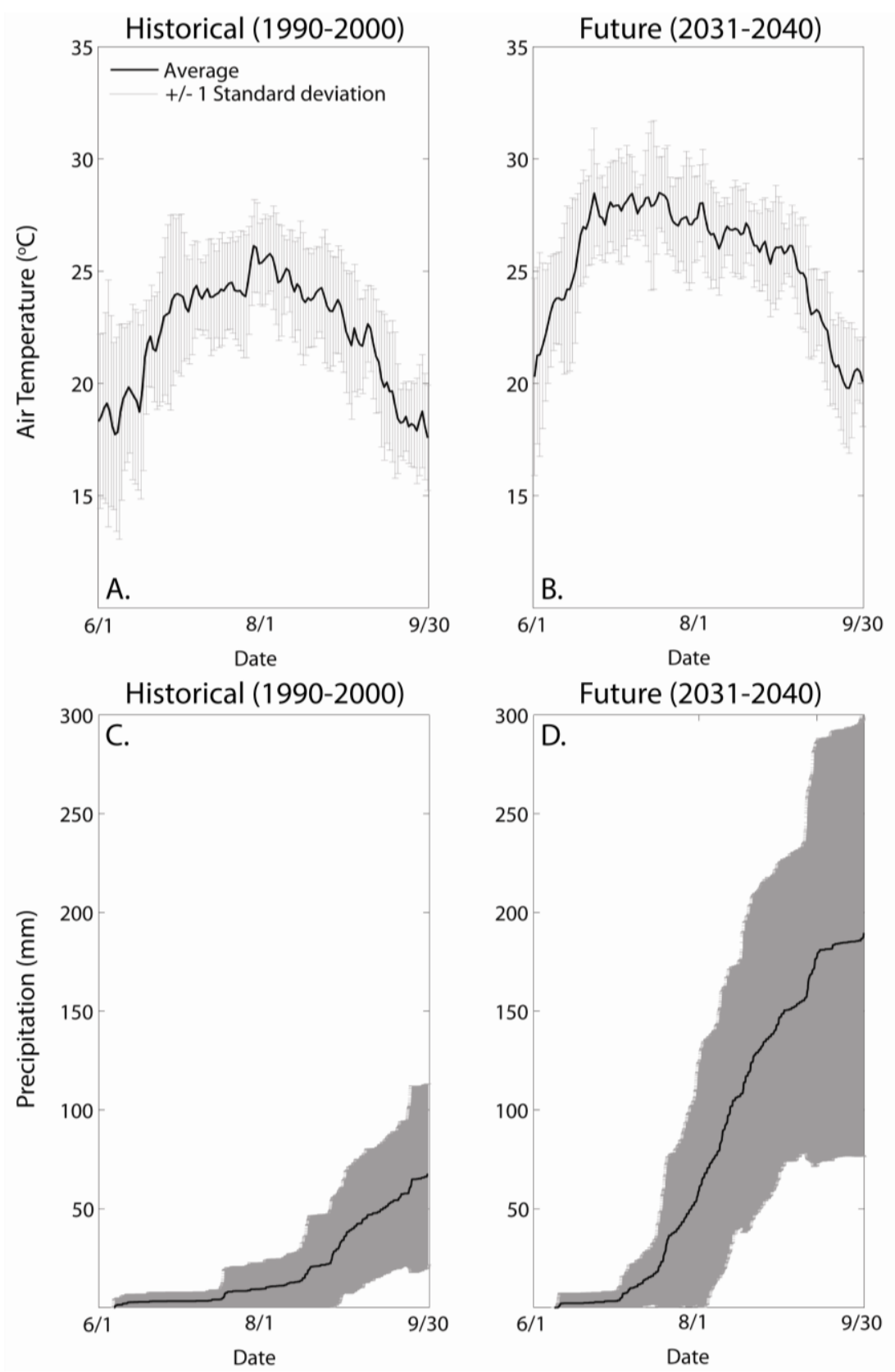

Fig. 7. Historical and future summertime climate projections spatially-averaged in the Beaver Creek of air temperature $(A, B)$ and cumulative precipitation $(C, D)$ averaged over each period (solid lines) and with interannual variability ( \pm 1 standard deviation shown as bars or shading).

Fig. 7 (Hawkins et al. 2015) 

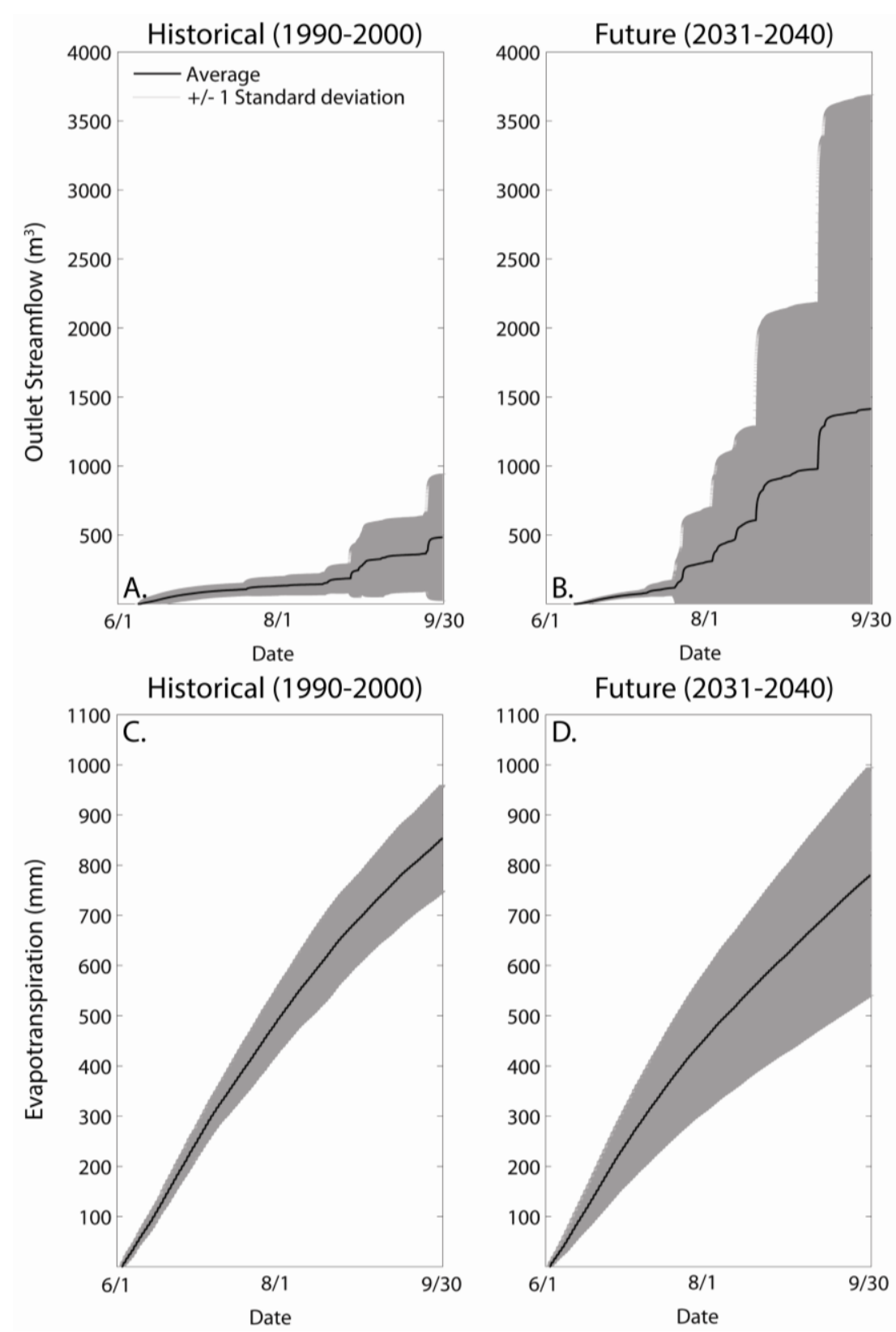

Fig. 8. Historical and future summertime climate projections spatially-averaged in the Beaver Creek of cumulative outlet streamflow (A, B) and cumulative evapotranspiration (C, D) averaged over each period (solid lines) and with interannual variability ( \pm 1 standard deviation, shading).

Fig. 8 (Hawkins et al. 2015) 

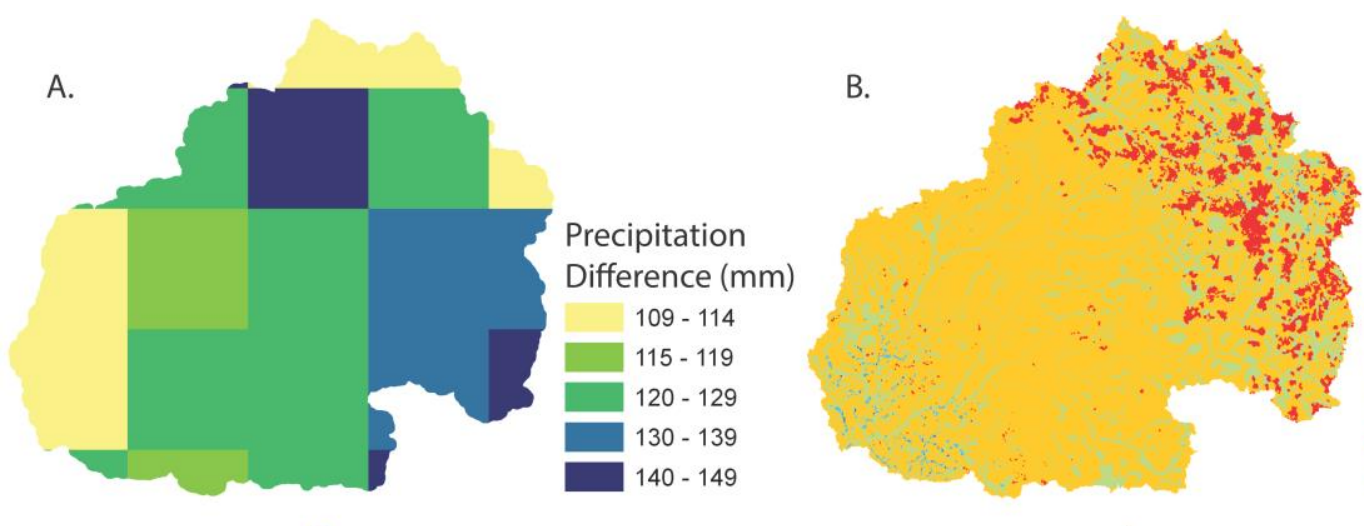

Relative Soil Moisture Difference (-)

0.000 to 0.000

0.001 to 0.002

0.003 to 0.008

0.009 to 0.032

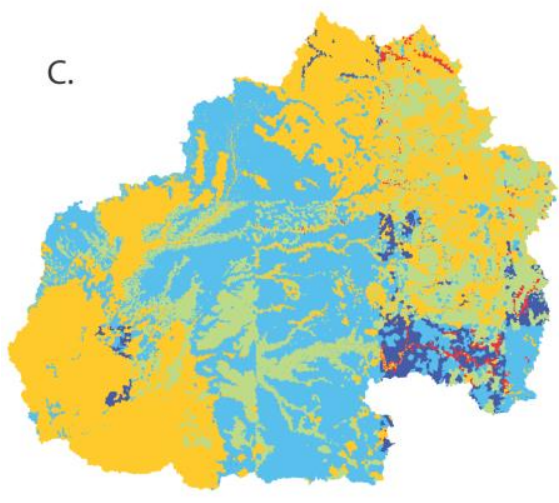

Runoff

Difference ( $\mathrm{mm}$ )

$-0.895--0.001$

$0.000-0.300$

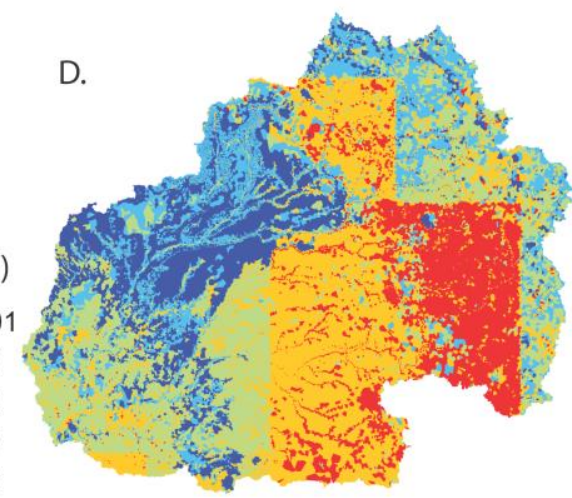

Evapotranspiration Difference (mm)

$0.301-0.500$

$0.501-0.900$

$0.901-1.700$

-195 to -61
-60 to -31
-30 to -16
-15 to -1
0 to 35

Fig. 9. Spatial variation of climate projection differences (average future period minus average historical period) in the Beaver Creek watershed for precipitation (A), relative soil moisture which is normalized by porosity (B), runoff (C) and evapotranspiration (D). Units are shown as a difference in mm and valid over an entire summer season (June 1 to September 30).

Fig. 9 (Hawkins et al. 2015) 


\section{Table Captions}

Table 1. Watershed areal coverage for soil and land cover classifications.

Table 2. Hydrologic components of the tRIBS model.

Table 3. Model parameters for the major soil and land cover classes. Definitions are detailed by Ivanov et al. (2004): $K_{s}$ is the saturated hydraulic conductivity, $\theta_{s}$ and $\theta_{s}$ are the soil moisture contents at saturation and residual values, $m$ is the pore size distribution index, $\Psi_{b}$ is the air entry bubbling pressure, $f$ is the hydraulic conductivity decay parameter, $A_{s}$ and $A_{u}$ are the saturated and unsaturated anisotropy ratios, $n$ is soil porosity, $k_{s}$ and $C_{s}$ are the soil heat conductivity and heat capacity, $p$ is the free throughfall coefficient, $S$ is the canopy storage capacity, $K$ and $g$ are the drainage coefficient and exponential parameters, $a$ is albedo, $h$ is vegetation height, $k_{t}$ is the optical transmission coefficient, $r_{s}$ is the stomatal resistance and $v_{f}$ is the vegetation fraction.

Table 4. Model performance metrics for flood event in 2007 (Fig. 5) and entire summer seasons in 2005, 2006 and 2007 (Fig. 6) at the three stream gauges, labeled as BCO (Beaver Creek Outlet, in plain text), WBC (Wet Beaver Creek, in italics) and DBC (Dry Beaver Creek, in bold). Metrics follow definitions in Vivoni et al. (2006). CC is the correlation coefficient (dimensionless, -), B is the bias (dimensionless, -), and MAE is the mean absolute error $\left(\mathrm{m}^{3} / \mathrm{s}\right)$. 


\begin{tabular}{lclc}
\hline \multicolumn{1}{c}{ Soil Class } & $\begin{array}{c}\text { Coverage } \\
(\boldsymbol{\%})\end{array}$ & Land Cover Class & $\begin{array}{c}\text { Coverage } \\
(\boldsymbol{\%})\end{array}$ \\
\hline & & & \\
Bedrock & 18.58 & Desert & 1.38 \\
Clay & 28.24 & Desert Grassland & 0.35 \\
Clay loam & 19.22 & Desert Riparian & 5.01 \\
Loam & 14.35 & Desert Shrub & 28.37 \\
Loamy Sand & 0.09 & General Development & 3.53 \\
Sand & 0.91 & Pinyon-Juniper & 27.57 \\
Sandy Loam & 6.73 & Ponderosa Pine & 33.73 \\
Silt Loam & 11.41 & Water & 0.06 \\
Silty Clay Loam & 0.41 & & \\
Water & 0.06 & & \\
& & & \\
\hline
\end{tabular}

Table 1. Watershed areal coverage for soil and land cover classifications.

Table 1 (Hawkins et al. 2015) 
Rainfall interception Rutter canopy water balance model

Surface energy balance Penman-Monteith equation, gradient method and force-restore equation

Surface radiation model Shortwave and longwave components accounting for terrain variability

Evapotranspiration Bare soil evaporation, transpiration and evaporation from wet canopy

Infiltration

Kinematic approximation with capillarity effects; single infiltration wave with top and wetting fronts

Lateral moisture flow

Topography-driven lateral unsaturated and saturated zone flow

Runoff production Infiltration-excess, saturation-excess, perched subsurface stormflow, groundwater exfiltration

Groundwater flow

Two-dimensional flow in multiple directions, dynamic water table

Overland flow

Nonlinear hydrologic routing

Channel flow

Kinematic wave hydraulic routing

Table 2. Hydrologic components of the tRIBS model.

Table 2 (Hawkins et al. 2015) 


\begin{tabular}{|c|c|c|c|c|c|c|c|c|c|c|}
\hline \multirow{3}{*}{$\begin{array}{l}\text { Parameter } \\
\text { (Unit) }\end{array}$} & \multicolumn{6}{|c|}{ Soil parameters } & \multirow{3}{*}{$\begin{array}{c}\text { Parameter } \\
\text { (Unit) }\end{array}$} & \multicolumn{3}{|c|}{ Land cover parameters } \\
\hline & \multicolumn{3}{|c|}{ Wet Beaver Creek } & \multicolumn{3}{|c|}{ Dry Beaver Creek } & & & & \\
\hline & Bedrock & Clay & $\begin{array}{c}\text { Clay } \\
\text { Loam }\end{array}$ & Bedrock & Clay & $\begin{array}{c}\text { Clay } \\
\text { Loam }\end{array}$ & & $\begin{array}{l}\text { Desert } \\
\text { Shrub }\end{array}$ & $\begin{array}{l}\text { Pinyon- } \\
\text { Juniper }\end{array}$ & $\begin{array}{c}\text { Ponderosa } \\
\text { Pine }\end{array}$ \\
\hline$K_{s}(\mathrm{~mm} / \mathrm{hr})$ & 1.0 & 3.0 & 14.3 & 1.0 & 3.0 & 14.3 & $p(-)$ & 0.85 & 0.70 & 0.50 \\
\hline$\theta_{s}(-)$ & 0.40 & 0.40 & 0.39 & 0.39 & 0.39 & 0.39 & $S(\mathrm{~mm})$ & 1.0 & 1.0 & 1.5 \\
\hline$\theta_{r}(-)$ & 0.10 & 0.10 & 0.08 & 0.09 & 0.09 & 0.08 & $K(\mathrm{~mm} / \mathrm{hr})$ & 0.10 & 0.10 & 0.12 \\
\hline$m(-)$ & 0.20 & 0.20 & 0.24 & 0.16 & 0.16 & 0.24 & $g\left(\mathrm{~mm}^{-1}\right)$ & 4.0 & 4.0 & 3.5 \\
\hline$\Psi_{b}(\mathrm{~mm})$ & -37 & -37 & -56 & -37 & -37 & -56 & $a(-)$ & 0.20 & 0.18 & 0.17 \\
\hline$f\left(\mathrm{~mm}^{-1}\right)$ & 0.0010 & 0.0050 & 0.0010 & 0.0010 & 0.0001 & 0.0010 & $h(\mathrm{~m})$ & 1 & 2 & 10 \\
\hline$A_{s}(-)$ & 200 & 200 & 200 & 200 & 200 & 200 & $k_{t}(-)$ & 0.6 & 0.5 & 0.3 \\
\hline$A_{u}(-)$ & 300 & 300 & 300 & 300 & 300 & 300 & $r_{s}(\mathrm{~s} / \mathrm{m})$ & 150 & 150 & 175 \\
\hline$n(-)$ & 0.48 & 0.48 & 0.47 & 0.48 & 0.48 & 0.47 & $v_{f}(-)$ & 0.2 & 0.5 & 0.8 \\
\hline$k_{s}(\mathrm{~J} / \mathrm{msK})$ & 0.7 & 0.7 & 0.7 & 0.7 & 0.7 & 0.7 & & & & \\
\hline$C_{s}\left(\mathrm{~J} / \mathrm{m}^{3} \mathrm{~K}\right)$ & $1.4 \times 10^{6}$ & $14 . \times 10^{6}$ & $1.4 \times 10^{6}$ & $1.4 \times 10^{6}$ & $14 . \times 10^{6}$ & $1.4 \times 10^{6}$ & & & & \\
\hline
\end{tabular}

Table 3. Model parameters for the major soil and land cover classes. Definitions are detailed by Ivanov et al. (2004): $K_{s}$ is the saturated hydraulic conductivity, $\theta_{s}$ and $\theta_{s}$ are the soil moisture contents at saturation and residual values, $m$ is the pore size distribution index, $\Psi_{b}$ is the air entry bubbling pressure, $f$ is the hydraulic conductivity decay parameter, $A_{s}$ and $A_{u}$ are the saturated and unsaturated anisotropy ratios, $n$ is soil porosity, $k_{s}$ and $C_{s}$ are the soil heat conductivity and heat capacity, $p$ is the free throughfall coefficient, $S$ is the canopy storage capacity, $K$ and $g$ are the drainage coefficient and exponential parameters, $a$ is albedo, $h$ is vegetation height, $k_{t}$ is the optical transmission coefficient, $r_{s}$ is the stomatal resistance and $v_{f}$ is the vegetation fraction.

Table 3 (Hawkins et al. 2015) 


\begin{tabular}{|c|c|c|c|}
\hline & $\begin{array}{c}\mathbf{C C}(-) \\
\mathrm{BCO}, W B C, \mathbf{D B C}\end{array}$ & $\begin{array}{c}\text { Metric } \\
\text { MAE }\left(\mathbf{m}^{\mathbf{3}} / \mathbf{s}\right) \\
\mathrm{BCO}, W B C, \mathbf{D B C}\end{array}$ & $\begin{array}{c}\mathbf{B}(-) \\
\mathrm{BCO}, W B C, \mathbf{D B C}\end{array}$ \\
\hline \multicolumn{4}{|c|}{2007 Flood Event } \\
\hline Gauge & $0.73,0.78, \mathbf{0 . 4 3}$ & $16.34,7.72, \mathbf{1 . 4 9}$ & $6.11,8.69, \mathbf{1 5 . 9 1}$ \\
\hline$N E X R A D$ & $0.66,0.74, \mathbf{0 . 5 7}$ & $11.74,2.09, \mathbf{0 . 3 9}$ & $4.60,2.94,4.77$ \\
\hline$N L D A S$ & $0.11,0.60, \mathbf{0 . 4 3}$ & $13.00,2.88, \mathbf{3 . 0 1}$ & $4.08,3.56, \mathbf{3 0 . 6 6}$ \\
\hline \multicolumn{4}{|c|}{2005 Summer Season } \\
\hline Gauge & $0.66,0.26, \mathbf{0 . 2 6}$ & $1.15,0.50, \mathbf{0 . 2 6}$ & $3.99,1.62, \mathbf{1 . 3 4}$ \\
\hline$N E X R A D$ & $0.64,0.48, \mathbf{0 . 6 7}$ & $0.92,0.34, \mathbf{0 . 2 3}$ & $3.25,0.99, \mathbf{1 . 4 1}$ \\
\hline$N L D A S$ & $0.16,0.17, \mathbf{0 . 0 6}$ & $0.56,0.31, \mathbf{0 . 2 1}$ & $1.45,0.55, \mathbf{0 . 4 8}$ \\
\hline \multicolumn{4}{|c|}{2006 Summer Season } \\
\hline Gauge & $0.46,0.08, \mathbf{0 . 7 7}$ & $2.51,0.81, \mathbf{0 . 3 9}$ & $10.08,4.31, \mathbf{1 . 5 3}$ \\
\hline$N E X R A D$ & $0.67,0.17, \mathbf{0 . 5 9}$ & $0.65,0.23, \mathbf{0 . 2 6}$ & $3.00,1.08, \mathbf{0 . 9 3}$ \\
\hline$N L D A S$ & $0.48,0.02, \mathbf{0 . 2 0}$ & $0.46,0.24, \mathbf{0 . 2 5}$ & $1.91,0.79, \mathbf{0 . 2 9}$ \\
\hline \multicolumn{4}{|c|}{2007 Summer Season } \\
\hline Gauge & $0.54,0.52, \mathbf{0 . 1 1}$ & $1.68,0.67, \mathbf{0 . 3 1}$ & $8.75,2.81,13.22$ \\
\hline$N E X R A D$ & $0.64,0.52, \mathbf{0 . 0 8}$ & $0.91,0.29, \mathbf{0 . 1 0}$ & $5.10,1.08, \mathbf{3 . 8 6}$ \\
\hline$N L D A S$ & $0.24,0.41, \mathbf{0 . 1 0}$ & $0.74,0.35, \mathbf{0 . 1 5}$ & $3.85,1.20, \mathbf{6 . 0 3}$ \\
\hline
\end{tabular}

Table 4. Model performance metrics for flood event in 2007 (Fig. 5) and entire summer seasons in 2005, 2006 and 2007 (Fig. 6) at the three stream gauges, labeled as BCO (Beaver Creek Outlet, in plain text), WBC (Wet Beaver Creek, in italics) and DBC (Dry Beaver Creek, in bold). Metrics follow definitions in Vivoni et al. (2006). CC is the correlation coefficient (dimensionless, -), B is the bias (dimensionless, -), and MAE is the mean absolute error $\left(\mathrm{m}^{3} / \mathrm{s}\right)$.

Table 4 (Hawkins et al. 2015) 